\title{
Implementing Indigenous Knowledge in Western Science Education Systems and Scientific Research on Alaska's North Slope
}

\author{
Linda Nicholas-Figueroa $^{1, *}$, Daniel Wall ${ }^{1}$, Mary van Muelken ${ }^{2} \&$ Lawrence Duffy $^{3}$ \\ ${ }^{1}$ Illisaġvik College, P.O. Box 749, Utqiaġvik (Barrow), AK 99723, USA \\ ${ }^{2}$ University of Alaska Fairbanks, Resilience and Adaptation Program, PO Box 757580, \\ Fairbanks, AK 99775, USA \\ ${ }^{3}$ University of Alaska Fairbanks, Department of Chemistry and Biochemistry, PO Box 6160, \\ Fairbanks AK 99775, USA \\ *Corresponding author: Iḷisagivik College, P.O. Box 749, Utqiagivik (Barrow), AK 99723, \\ USA. E-mail: lnicholasfigueroa@alaska.edu
}

Received: July 7, 2017 Accepted: October 23, 2017 Published: November 15, 2017

doi:10.5296/ije.v9i4.12148 URL: https://doi.org/10.5296/ije.v9i4.12148

\begin{abstract}
The inclusion of Indigenous knowledge, informal lessons, and place-based instruction in science curricula has shown many positive results in both the classroom and laboratory. Inviting Alaska Native Elders and researchers into local classrooms to co-instruct scientific concepts has increased student understanding and engagement. Field trips further expose students to research conducted on Alaska's North Slope underlining the environmental and cultural implications of local community issues and the broader scientific concerns. Teaching students the traditional ways of knowing and the correlating Western science concepts develops an appreciation for both perspectives that directly strengthens students' knowledge and reinforces cultural values.
\end{abstract}

Keywords: Indigenous knowledge, place-based, STEM, environment, culture, Elders, community 


\section{NI Macrothink}

\section{Introduction}

Tied to cultural and spiritual identity and passed down from generation to generation, Traditional Ecological Knowledge (TEK) or Indigenous knowledge evolves in tandem with a changing environment (Bartlett et al., 2012; Cochran, 2013). This evolution of knowledge interacts with practical values informing world view and culture. Worldview, a particular group's perspective and ways of knowing, varies between cultural groups. Many contemporary educators consider world view and Indigenous knowledge as important as the concepts taught by Western style education. Indigenous knowledge can be woven into Western education, science, and research in a variety of ways using educational approaches that follow an informal approach and place-based settings (Figure 1). When woven together, the two systems can co-exist allowing for the Indigenous population to have a better understanding of both worlds (Bartlett et al., 2012). Many higher institutions are gradually increasing the adoption of informal and place-based instruction with positive impacts on the students learning gains (Dubiel et al., 1997; Palmer et al., 2009; Kirby, 2014; Medin \& Bang, 2014; Reano and Ridgway, 2015; Nicholas-Figueroa et al., 2016; Van Doren \& Duffy, 2016).

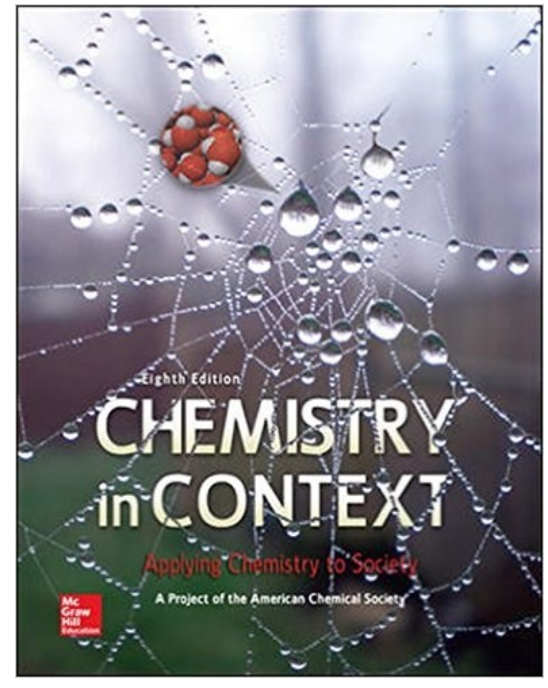

Figure 1. Cover Chemistry in Context: An illustration of a spider web indicating how knowledge is woven across disciplines and cultures

\section{Traditional Education}

\subsection{Pre-Westernization and Alaska Native Knowledge}

Although Alaska Natives have a great variety of cultural traditions, there are a number of common features, many of which help shape their ways of knowing. Oscar Kawagley (2006) wrote, "Native peoples developed many rituals and ceremonies with respect to motherhood and child rearing, care of animals, hunting and trapping practices, and related ceremonies for maintaining balance between the human, natural, and spiritual realms." Schooling, in essence, involved Elders teaching the youth to maintain balance in their environment (Nicholas-Figueroa et al., 2015). 
For example, Elders taught males to be active listeners (Jones-Sparck, 2011) during "lessons" that included developing prowess in hunting, fishing, interpreting environmental signals, survival and other life skills. Lucy Jones-Sparck (2011) explains, "when they dealt with the subject of survival tools, they included the science of nature, how to read the sign about what nature was about to do or just did, and how to respond in respect." Mothers and Elder women in the community taught young women to tend to domestic skills, pregnancy and child rearing, and spiritually support their husbands when they were hunting (Kawagley, 2006).

These lessons continue to meet the needs of Alaska Natives and are directly related to their ecological systems (Nelson, 1983); the environment is an integral part of their learning process (Kawagley, 2006) and is tied to Native peoples' myths, rituals, and ceremonies (Freeman et al., 1988; Locust, 1988; Feinup-Riordan, 1990). The information reflects the harmony that exists between the natural and spiritual worlds (Kawagley, 2006). Referring to Yup'ik people, Harold Napoleon wrote, "Yuuraraq, the way of the human being, encompassed the spirit world in which the Yup'ik lived. The Yup'ik, the land, rivers, heavens, seas, and all that dwelled within were spirit, and therefore, sacred (Napoleon, 1991)." Beginning in the $18^{\text {th }}$ century, colonization perpetrated by Western societies, upset the natural balance Alaska Natives had with their environment, spiritual direction, and their legacy for subsequent generations. Western educational methods were imposed on Alaska Natives in an effort to supplant traditional ways of learning (Kawagley, 2006) with Western cultural values.

\subsection{Indigenous Knowledge and Western Education}

In sharp contrast to Western educational reductionism and abstractness, Indigenous knowledge is holistic and does not essentially separate ecological knowledge, human beings or nature from the world (Cajete \& Pueblo, 2010). In the article, "Culture, Community and the Curriculum" Ray Barnhardt (1981), describes the many different educational and learning approaches for engaging students of Alaska Native and other cultural minorities.

Minority students residing in their own ethnic communities are raised with their community cultural identities and values. For many peoples, especially American Indians and Alaska Natives, culture is the centerpiece for continued knowledge towards survival. In the past, education was part of everyday activities. The student learned by "doing." Today students sit long hours in a classroom being talked to with very few options to execute what they supposedly learned. Now, a prime focus is to integrate these teachings into higher educational institutions.

One direction to overcome this challenge is to convert the usual formal educational format to an informal practice which provides for the inclusion of Indigenous knowledge in teaching practices. McGloin et al. (2009) strongly supports encouraging Indigenous peoples to teach their cultural ways of knowing throughout the educational system. The authors further state that Elders and other knowledgeable individuals should be recognized for their cultural knowledge at a level comparable to the Western Doctorate of Philosophy degree, leading to employment as adjuncts or associate positions within the university system. The University of Alaska and Ilisagivik College of Utqiagivik (Barrow), AK bestow Honorary Degrees to Alaska Native Elders each year during the commencement ceremony. 
Bartlett et al. (2012) describes informal education as a weaving process between Indigenous knowledge systems and mainstream or Western education systems and involves those holding Indigenous knowledge, such as Elders, along with Western science experts. It is important that Indigenous knowledge be recognized as an individual knowledge system standing alongside Western education systems (Iwama et al., 2009; Bartlett et al., 2012). In Bartlett et al. (2012), Albert Marshall, an aboriginal Elder of the Mi'kmaw Nation in Canada, defines this weaving as "Two-Eyed Seeing," a learning process that demonstrates the strengths of Indigenous knowledge (one-eye) and the strengths of Western knowledge (the other eye). Together these eyes are advantageous to everyone (Bartlett, 2006; Hatcher et al., 2009; Iwama et al., 2009; Hatcher \& Bartlett, 2010; Marshall et al., 2010; Bartlett, 2011, 2012; Bartlett et al., 2012; IISH website, http://www.integrativescience.ca). Elder Marshall continues to say that "we need to weave back and forth between our knowledges because in a particular set of circumstances, it may be that one has more applicable strengths than the other, yet with changing circumstances this can easily switch (Bartlett et al., 2012)."

Of equal importance is the understanding that traditional knowledge is always changing. Elder Murdena Marshall, also a member of the Mi'kmaw Nation, states that Indigenous knowledge "was never meant to be static and stay in the past; rather it must be brought into the present so that everything becomes meaningful in our lives and in our communities (Bartlett et al., 2012)." Interviewed by the Wisdom of the Elders radio program, former Alaska Native Science Commission executive director and former Inuit Circumpolar Council chair, Patricia L. Cochran, reflected on the value of traditional knowledge. The Iñupiat Elder told listeners: "Traditional knowledge builds. And that's what it's about: it's just not knowledge from the past; it really builds from what I know today and what generations will teach (P. Cochran, 2013)."

\subsection{Strategies for Implementing Indigenous Knowledge in Conjunction with Western Science}

Like traditional knowledge, Western science builds from previous knowledge, but is constrained by the boundaries of Western scientific methodologies. Traditional knowledge, however, is contingent upon an ever-changing world; it is constantly evolving as new and/or unforeseen situations or conditions are encountered.

Traditional knowledge is intricately entwined with subsistence activities such as hunting and gathering (Kawagley \& Barnhardt, 1998). "Native people know a great deal about the flora and fauna, and they have their own classification systems and versions of meteorology, physics, chemistry, earth science, astronomy, psychology (knowing one's inner world), and the sacred (Burgess, 1999)." When appropriately woven together, traditional knowledge and Western science can deliver innovative and unique information that is absent when conveyed only by Western ways.

Kimmerer (2002) discusses how traditional knowledge can be merged with biological sciences, including detailed observations of flora and fauna and the surrounding ecological environment. This knowledge can substantially support scientific hypotheses or redirect scientific research (Kimmerer, 2002). For example, scientists may miss vital information due to short term observation as opposed to years of observation performed by Indigenous 
peoples who impart knowledge through the generations. This kind of long term exposure to the subject is particularly useful in both hypothesis formulation and the interpretation of results. Western science may yield specific quantifiable observations, yet Native voices may be particularly helpful in raising the right questions and in relating the findings of a particular study to a larger body of practical knowledge. For example, Nakashima (1993) compared collaborative reports of Hudson Bay eider (Somateria mollissima sedentaria) developed between wildlife biologists and Iñuit hunters. The hunters were more knowledgeable about the birds' winter behavior, mortality, and demography. Nakashima suggests that Iñuit knowledge and Western science combined (or woven together) complements environmental impact assessment studies (Nakashima, 1988). The strength of Indigenous knowledge, with an advanced local understanding applied, is illustrated by studies of: fisheries (Berkes, 1977), caribou age structure (Mander, 1991), bowhead whale census (Huntington et al., 1999), forest fungi (Richards, 1997), wolves (Stephenson, 1982), and plants (Anderson, 1996; Turner et al., 2000; Kimmerer, 2002).

Taught through everyday activities such as observation, storytelling, dance, and song, children and students effortlessly acquire Indigenous knowledge from these practices. Kawagley and Barnhardt (1998) describe how these activities can be woven into the Western knowledge system (or vice versa) using the following example:

To bring significance to learning in indigenous contexts, the explanations of natural phenomena cast first in Native terms to which students can relate, and then explained in Western terms. For example, when describing an eddy along the river for placing a fishing net, it should be explained initially in the indigenous way of understanding pointing out the currents, the movement of debris and sediment in the water, the likely path of the fish, the condition of the river bank, upstream conditions affecting water levels, the impact of passing boats, etc. Once the students understand the significance of the knowledge being presented, it can then be explained in Western terms, such as flow, velocity, resistance, turgidity, sonar readings, tide tables, etc., to illustrate how the modern explanation adds to the traditional understanding (and vice versa). All learning should start with what the student and community know and are using in everyday life. The Native student will become more motivated to learn when the subject matter is based on something useful and suitable to the livelihood of the community and is presented in a way that reflects the interconnectedness of all things.

Many post-secondary institutions have successfully engaged Elders in the classroom; have recognized Indigenous knowledge and cultures as part of student learning gains; and support community engaged research and learning approaches (Nicholas-Figueroa et al., 2016; Van Doren and Duffy, 2016). A number of strategies for accomplishing these goals are presented by Knudson (2015): 1) fostering of indigenous knowledge is advantageous in supporting campus growth: physical space, events and curriculum content; 2) student engagement need not be limited to a specific cultural background - involving all cultures will assure a means of knowing in multiple ways; 3) allotted time is essential for instructors to compile materials/resources needed to formulate engaging lessons (Machtmes et al., 2009; Potter, et 
al., 2003); and 4) hands-on learning is a key component to learning along with realistic projects each focusing on traditional ecological knowledge (Battiste, 1998, Castellano, 2000; Battiste, 2002).

\section{Place-based Education}

\subsection{Culture and Earth/Environmental Science}

A wide variety of regionally adapted culture and earth science curricula (classroom and field courses) for Native Americans and First Nations peoples bridge the gap between Indigenous groups, scientists, and educators (Riggs, 2004). For example, Reano and Ridgway (2015) describe how a geological discipline, such as stratigraphy, has cultural relevance to the Native American community of Acoma Pueblo, New Mexico: Geologists use stratigraphic nomenclature to describe the Earth's physical features, identifiable patterns and depositional environments while the Acoma Pueblo community members' describe the same stratigraphic intervals in terms of cultural uses, such as in making pottery, building their homes out of rock and mud, and farming the land.

The environment or "sense of place" (Semken, 2005; Medin \& Bang, 2014; Lowan-Trudeau, 2015) has significant meaning for Indigenous peoples and it is important to link educational concepts to the physical and cultural landscape (Semken \& Morgan, 1997; Kawagley \& Barnhardt, 1999; McCarty, 2002). Place-based instruction accomplishes this objective by acknowledging a sense of place and linking the value of/connection to locations reflecting important cultural and educational beliefs (Semken, 2005). Western teachings are primarily concentrated in the classroom and rely on textbooks and laboratory simulations; whereas, place-based teachings occur in the field (outdoor environment) or in a community setting (Semken, 2005; Van Doren and Duffy, 2016). As the following examples illustrate, culture and environmental science is an ideal discipline for place-based instruction. Five general guidelines for successful implementation have been distilled (MacIvor, 1995; Lieberman \& Hoody, 1998; Kawagley \& Barnhardt, 1999; Cajete, 2000; Woodhouse \& Knapp, 2000; Gruenewald, 2003; Semken, 2005) and while these guidelines are based on teaching American Indian or Alaska Native students, they also suggest implementation strategies for place-based teaching in any context. These guidelines are applied to course content connected to the Alaska's North Slope changing climate.

- Content is focused explicitly on the geological and other natural attributes of a place. The effects of global warming are most profound in the Arctic. Students on the North Slope of Alaska learn how the effects of a warming climate ranging from the increased rate of sea-ice decline, melting permafrost, and migration changes in plants, animals, and microorganisms relates directly to their own communities.

- Content promotes and supports ecologically - and culturally - sustainable living in that place. Bradley et al. (2005) discussed the impact of a warming climate on free living bacteria, an increase of which may promote diseases affecting marine fish, caribou, fox, lemming, sea otters, and other arctic species, a major 
component of the rural Alaska Native diet. New microbial diseases affecting subsistence foods will directly impact the health of subsistence communities.

- Content is taught by authentic experiences in that place, or in an environment that strongly evokes that place. Field trips are incorporated into the lessons to prompt a better understanding of the materials being covered. A trip to the NOAA Utqiagivik (Barrow) Research Laboratory where greenhouse gasses are measured leads to a conceptual understanding of carbon dioxides role in global warming (Nicholas-Figueroa et al., 2016).

- Content enriches the sense of place for students and instructor. Local Utqiagivik (Barrow) Elders share their experiences and observations of climate change in an interactive discussion with students, research scientists, and instructors (Nicholas-Figueroa et al., 2016). Due to a loss of sea ice with warming waters, storms are becoming more frequent, which leads to beach and land erosion (Elder Nate Olemaun, personal communication, 2012).

- Content integrates, or at least acknowledges, the diverse meanings that place holds. Gwich'n and Iñupiat communities rely on successful caribou hunts to meet basic cultural and spiritual needs. All parts of the animal are used for food, clothing, tools, and sewing umiaqs, the traditional whaling canoe. Today, the spiritual belief is that "every caribou has a bit of the human heart in him; and every human has a bit of caribou heart (http://arcticcircle.uconn.edu/ANWR/anwrgwichin.html)."

\subsection{Climate Change: global to local}

Nicholas-Figueroa, et al. (2016) demonstrated that informal and place-based learning is an effective means of teaching science, technology, engineering, and mathematics (STEM) concepts. A summer science camp for middle school and high school students, Climate and Permafrost Changes on the North Slope: In Cultural Context, was held in Utqiagivik (Barrow), AK. Educators, researchers, and Elders served as instructors and each provided a unique perspective on the selected topic. For example, the relationship of the carbon cycle to a changing climate was initially presented by the educators. Research scientists then reinforced these lessons by sharing how this knowledge applied to their work including weather patterns, arctic wetlands, bird migration, (Rothschild \& Duffy, 2003), rural pollution and ecosystem interactions (Loring \& Duffy, 2011), impacts of greenhouse gasses on the environment; and the changing permafrost (Streever et al., 2011). Elders have contributed their knowledge and reminded students of important issues relevant to the students' communities and environment: economics; storms; sea ice; polar bears; walrus; whales; caribou; ice cellars; invasive species, biogeochemical cycles, and combustion (Figure 2A and 2B). 


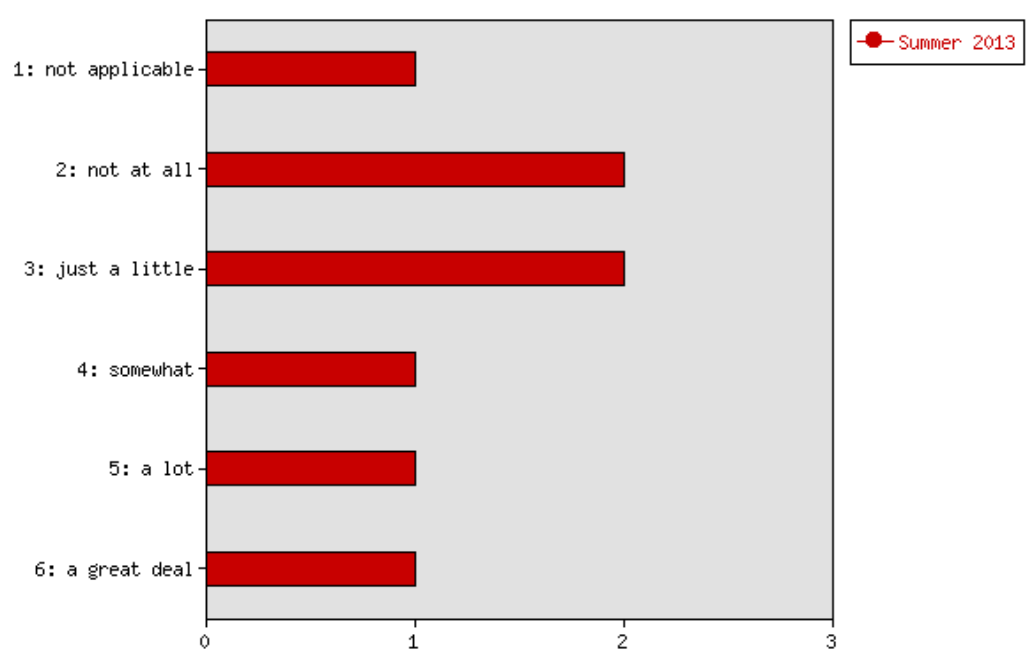

Figure 2A. Pre-course assessment. Illisagivik College student evaluation of the knowledge and understanding of the carbon biogeochemical cycle and combustion

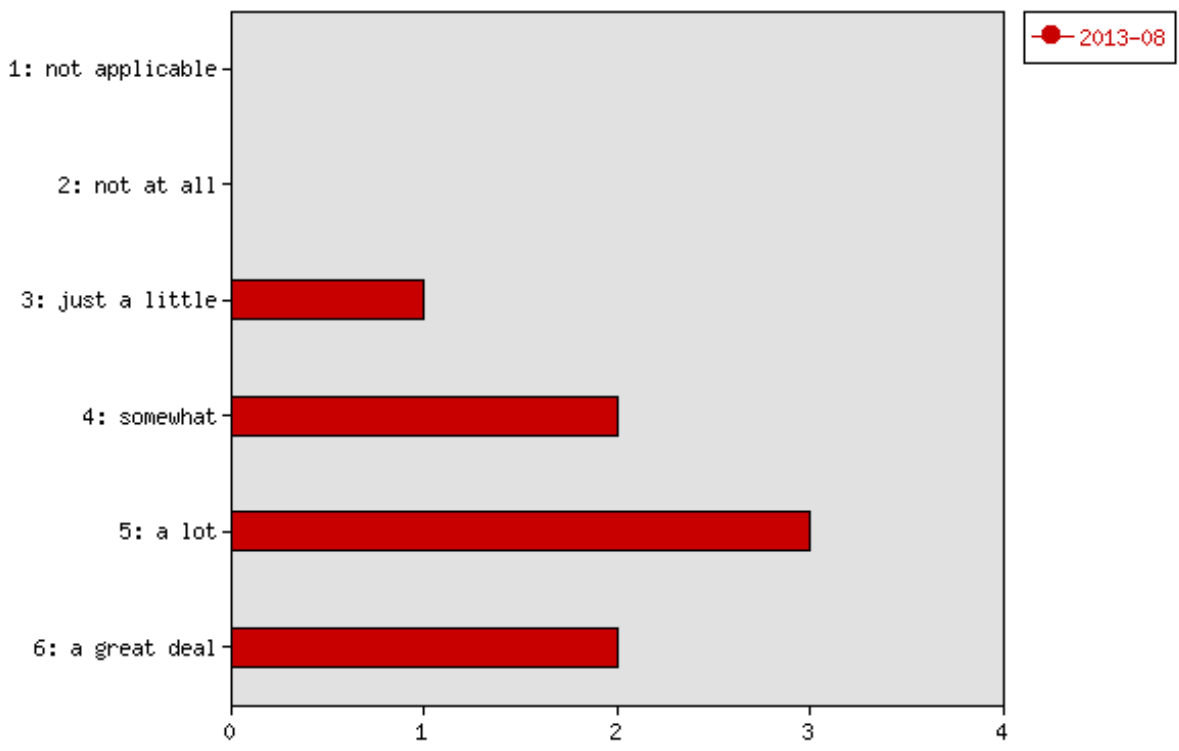

Figure 2B. Post-course assessment. Illisagvik College student evaluation of the knowledge and understanding of the carbon biogeochemical cycle and combustion

\section{Scientific Research and Gathering Traditional Knowledge}

4.1 Implementing Educational use of Indigenous Knowledge into Informal Education and Research Practices in a Northern Alaska Community

Middle and high school Alaska Native students' first interest in STEM education often coincides with exposure to informal learning (Van Doren \& Duffy, 2016). Interest can build 
as a student progresses from presenting an in-class science project to competing in a science fair. Alaska Federation of Natives-NSF Rural Systemic Initiative encouraged students to design their research projects with the assistance of parents, and in some cases, local college students and scientists. Incorporating an Indigenous theme integrates culture and values and add further depth and meaning to the project. The resulting positive experience engages students who, early on, may have difficulties with abstract Western science concepts. For example, the concept of combustion can be explained through traditional uses of whale oil on Alaska's North Slope, a familiar substance. Local Elders, an integral part of the review team, score the use of traditional knowledge and how traditional knowledge adds value to the project.

From a global science perspective, strategies for overcoming cultural barriers between scientists and rural communities should include methods to work directly with the communities. The framework suggested by Semken (2005) was used with modifications by Nicholas-Figueroa and Wall at Ilisagivik College. Researchers should be encouraged to consider community concerns and strive to build collaborative relationships. Recommendations from our experience (Nicholas-Figueroa, 2017) include:

-Seek expert advice from Elders prior to beginning the research. Traditional knowledge is passed down through the generations; therefore, Elders have much to contribute throughout the research process. Recognize that not all Elders are experts in every topic. Ask community members for assistance identifying individuals most knowledgeable of the research topic. "Research that bridges the gap between local knowledge and science can provide reciprocal benefits to scientists and local communities (Huntington, 2000; Carmack and Macdonald, 2008; Weatherhead et al., 2010; Huntington et al., 2011) (Jones, et al., 2015)."

- Recruit additional research team members, such as local students, who can create interest and contribute local knowledge. Outreach presentations to middle/high school students, including opportunities for field visits, are encouraged. Students are rarely introduced to research practices, even those carried out in their own communities. Local hunters are an additional source of knowledge. For example, if investigating the decline of Arctic caribou, it would be wise to recruit local hunters to elicit their observations and discuss their thoughts on the reasons for these changes. Local hunters can provide expertise and may be willing to assist with sample collections. "Traditional knowledge and local observations have been used in conjunction with scientific methods to gain a better understanding of how rural people rely on physical and natural phenomena (Krupnik and Jolly, 2002; Chapin et al., 2006; Carmack and Macdonald, 2008; Pearce et al., 2009; Weatherhead et al., 2010; Druckenmiller et al., 2013; Eicken et al., 2014) (Jones et al., 2015)."

- Share the research ideas and goals with the community before beginning a new project and provide periodic updates (especially when there are significant findings). Informal presentations with question and answer sessions between 
community members and researchers are an effective means of communication. Refreshments or a community meal are always welcome. Hospitality does more than establish a friendly tone; sharing information while enjoying a meal may be more culturally appropriate than a meeting. Specific cultural practices may also play a role. When appropriate, gift exchanges and/or local conventions of address, seating, and personal conduct should be considered. "A desirable research objective would aim to produce tools or other research products that will also benefit local collaborators (Nadasdy, 1999; Cruikshank, 2001) (Jones et al., 2015)."

Community dialogue benefits community members and researchers. Community members have a "stake" in the project and resulting knowledge and researchers learn from the community. Indigenous sources can comment on results and suggest ideas for future study. They may also, at their own discretion, promote the study by taking a role in communicating the results to others.

\section{4..2 Introducing TEK and Research Conducted on the North Slope of Alaska into Place-Based Education}

Alaska's North Slope Borough (NSB), 300 miles above the Arctic Circle, is home to $\sim 10,000$ Iñupiat people and a diverse, copious collection of marine mammals, fish, plants, and wildlife (Streever et al., 2011; Nicholas-Figueroa et al., 2015). The North Slope is on the forefront of environmental and ecological change experiencing an average $3{ }^{\circ}$ Fahrenheit temperature increase over the past 60 years (EPA, 2015). The impact of climate change, the focus of major national scientific research, is often best studied from the NSB's eight local villages or communities (Figure 3). Yet, despite the abundant funded research conducted, students are rarely exposed to the research, especially those related to Alaska communities' wellbeing or hunting and gathering activities.

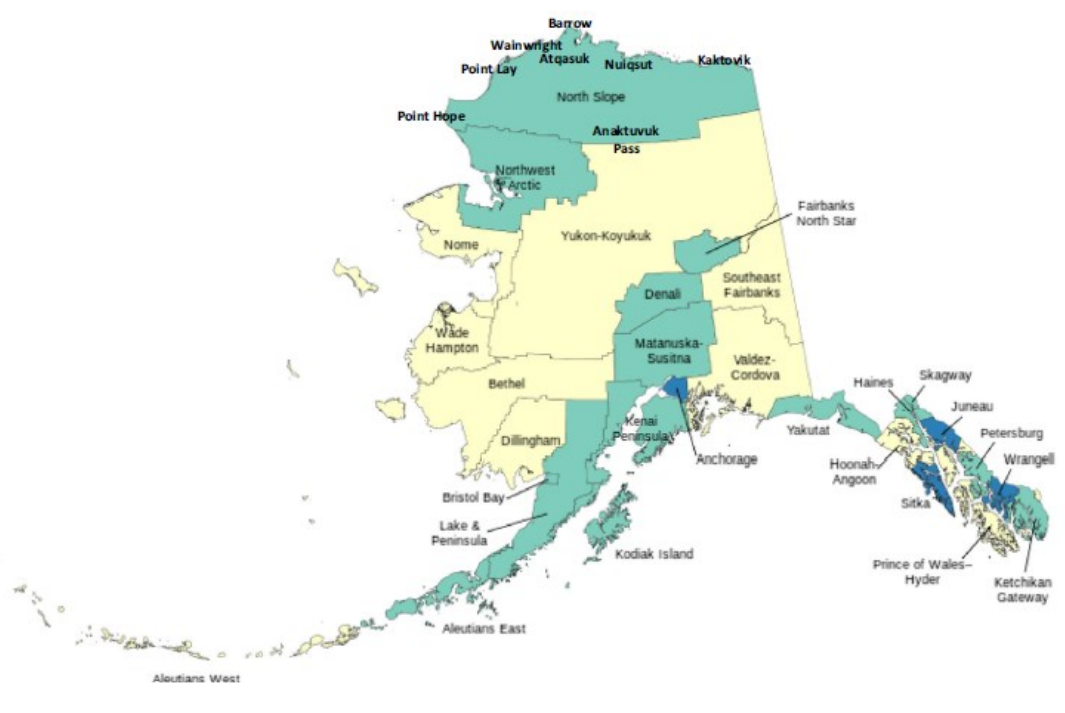

Figure 3. Map of the North Slope Borough (NSB) villages (Anaktuvuk Pass, Atqasuk, Barrow, Kaktovik, Nuiqsut, Point Hope, Point Lay, and Wainwright) used 
with permission from the NSB department of Planning/GIS Division (source, http://www.north-slope.org/assets/images/uploads/NSBCensus2010.pdf.).

NSB students' understanding of STEM subjects can be greatly enhanced by using place-based instruction and including exposure to the scientific community, Elders' Indigenous knowledge, and tapping their own ecological experience (Figure 2). Scientific techniques are easily reinforced using a relevant, culturally germane setting or lab exercise as illustrated by the following examples.

-Hunted by humans for both meat and eggs, the Glaucous gull is a fierce predator consuming eggs, chicks, small mammals and fish, all part of the community's subsistence diet. The gull provides a good example of how a warming climate impacts the food chain and the local ecological balance. Our lesson included a discussion with Elders describing the birds' changing movement patterns. Ideally students would be trained to collect data (movement, Elder/hunter knowledge, and other data) and work with researchers to hypothesize how changes in these patterns impact the local environment (Figure 4A and 4B). The preparation of a scientific poster from the obtained data would further enhance the experience and record the activity.

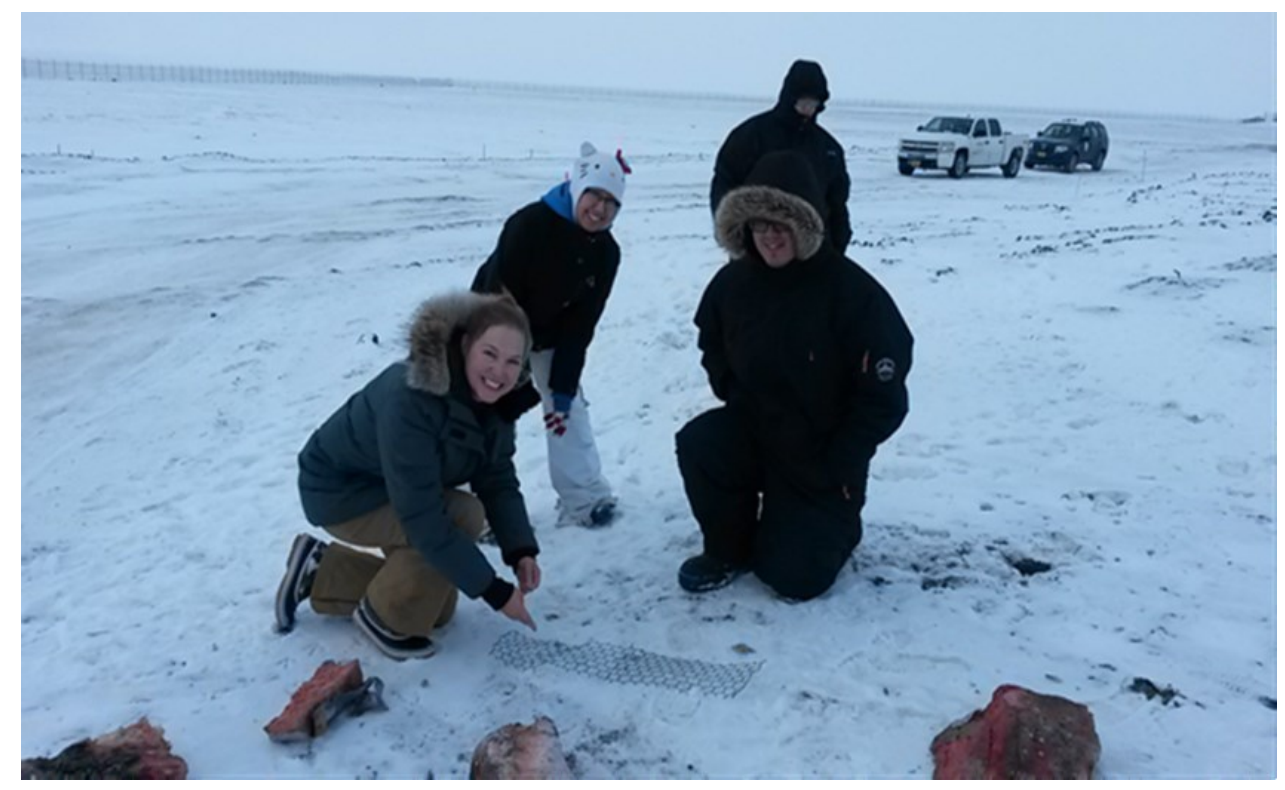

Figure 4A. Ilisagivik students observing the placement of a gull trap. Photograph taken by Linda Nicholas-Figueroa 


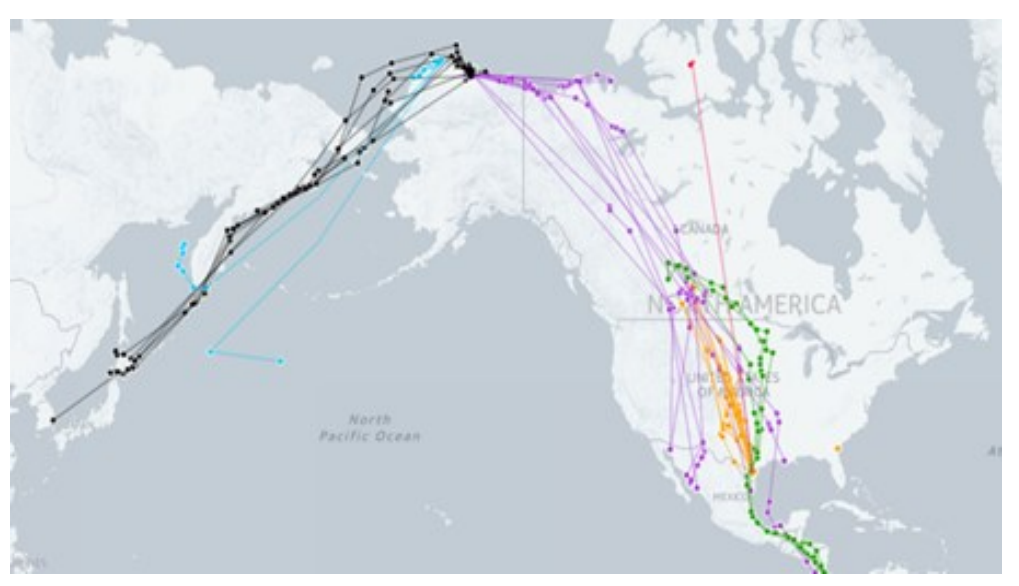

Figure 4B. Migration of a Glaucous Gull from Barrow, Alaska (blue line). "A Glaucous Gull transmitter woke up this morning and pinged from the southern Kamchatka Peninsula, Russia. This is the bird's first winter and first migration, and I totally didn't expect a juvenile bird to go there! The bird traveled over 1,800 miles (Autumn-Lynn Harrison, March 4, 2016; Smithsonian Conservation Biology Institute, Migratory Bird Center).” www.migratoryconnectivityproject.org/livetracks

-The Bowhead whale, a major dietary food source and symbol of Iñupiat spiritual and cultural identity, provides another concrete example of how place-based instruction augments student learning. During whaling season, North Slope Borough Department of Wildlife Management (NSB-DWM) employees often obtain organs from harvested whales. Students visit their laboratory and observe biological studies such as the lung volume/respiration rate study (Figure 5). Craig George (NSB-DWM) connected the concept of Bowhead basic "energetics" and food requirements with summer and winter feeding areas (personal communication, October 2013). Andreas Fahlman, Texas A\&M University, continued the discussion by teaching how the lung volume/respiration rate is used to estimate energy or food requirements (personal communication, October 2013). Students completed the lesson by calculating their personal lung volume/respiration.

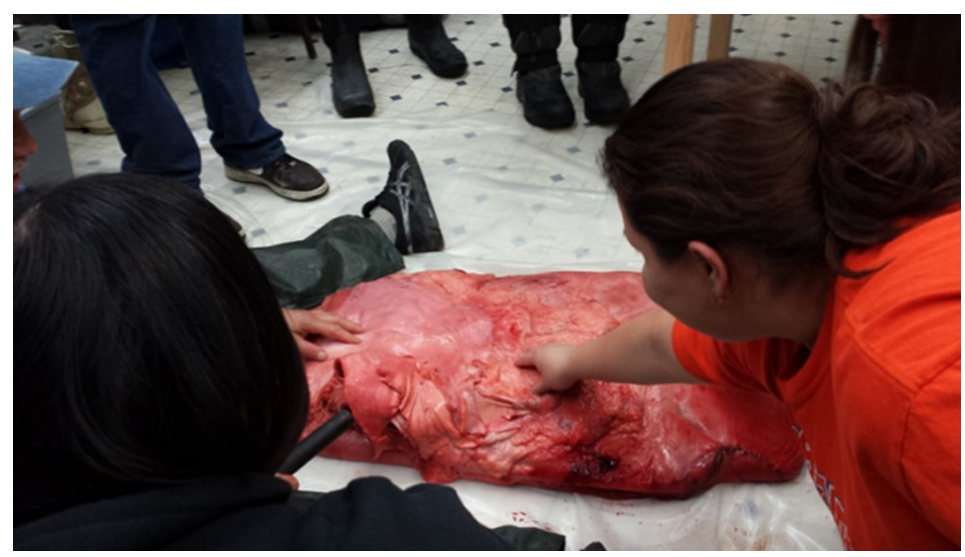

Figure 5. Student observations of the inflation of a Bowhead whale lung. Photograph taken by Linda Nicholas-Figueroa. 
- Basic atmospheric chemistry concepts of the chemical composition of individual aerosol particles (real time sizing, the method for determining how these particles impact the Arctic environment) were explained using black carbon as an example. The travel path of black carbon from industrialized countries to the Arctic was demonstrated in a research presentation and reinforced with a field trip to see the Aerosol Time-Flight Mass Spectrometer (Figure 6). Ideally, a dialogue or exchange of information occurs between students, Elders, instructors, and research personnel. Students are always encouraged to ask questions and/or discuss their concerns. A follow up essay describing what was learned and proposing possible solutions further reinforces the concepts discussed.
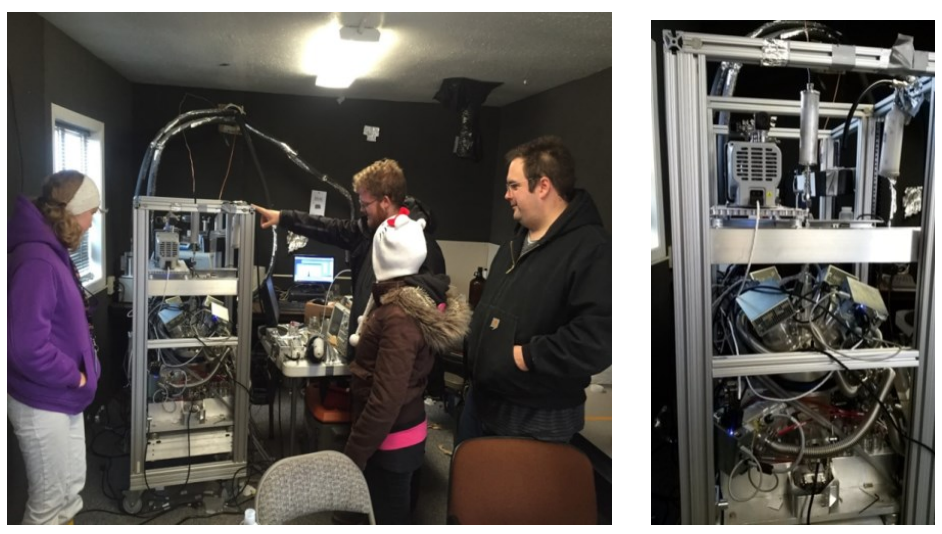

Figure 6. Aerosol Time-of-Flight Mass Spectrometer real time sizing and chemical composition of individual aerosol particles. Allows usage of "chemical fingerprints" to identify each particle type. Photographs taken by Linda Nicholas-Figueroa

The Indigenous observations of sea ice provide numerous scientific lessons that relate directly to an individual's health and safety. Webster and Zibell in the Iñupiat Eskimo Dictionary (1970) list 28 words that define ice. Table 1 lists a few of these words to include sea ice definitions or descriptions that assist a hunter's evaluation of ice conditions.

Table 1. English translations for Iñupiaq terms for sea ice and sea ice formations

\begin{tabular}{ll} 
Iñupiaq & English Translation \\
Siku & Sea ice \\
Sikuliirak & Ice thick enough to walk on \\
Sikulikiruk & Ice is in the process of break-up \\
Aunnik & Rotten ice (unsafe) \\
Tuvak & Landlocked Ice; Shorefast ice \\
Kisisak & Grounded ice pile (keeps landlocked ice from floating away), \\
& ice floes \\
Ivunik & Ice pressure ridge \\
Puktaak & Iceberg \\
Sarri & Ice pack \\
Uinik & Lead (open water between landlocked ice and pack ice) \\
\hline
\end{tabular}


Safety implications and changing conditions affect a hunter's ability to exploit resources in this dynamic setting. David "Masaq" Leavitt, Jr., a visiting Elder, described the importance of paying attention to wind and sea current changes, "shifts in the wind and sea currents are particularly critical insofar as they indicate the likelihood that ice will soon break up" (personal communication, October 2016). Figure 6 illustrates the significance of understanding words and definitions. The ability to differentiate between an ice floe, ice that is essentially floating on the open sea and shorefast ice which is anchored to the ground below is critical knowledge for survival on the ice. Elders commonly assess ice conditions with a degree of nuance difficult to capture in discrete scientific observations.

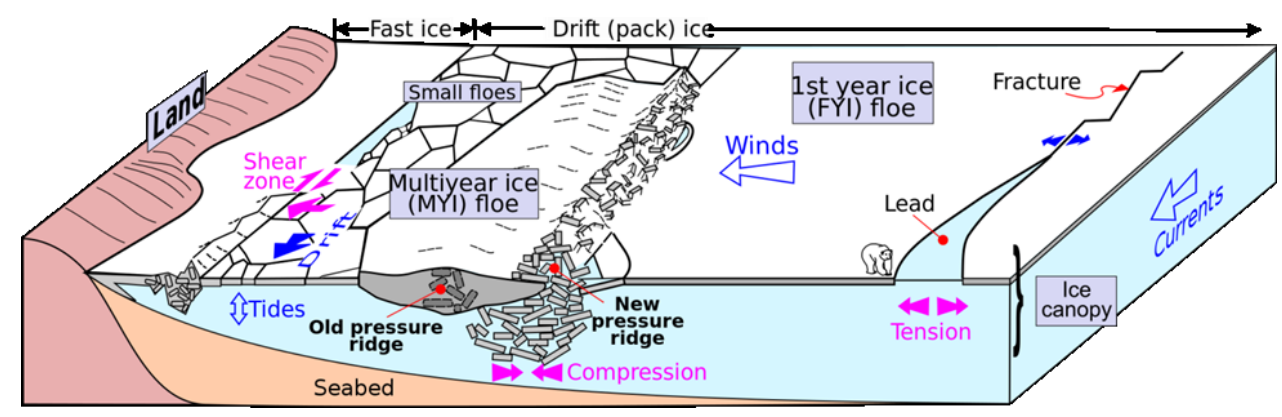

Figure 6. Hypothetical sea ice dynamics scenario showing some of the most common sea ice features. https://en.wikipedia.org/wiki/Sea_ice

\section{Conclusion}

Because traditional ecological knowledge is inherently dynamic, successful incorporation into higher education has more to do with building social networks than data-bases. Purposeful communication between indigenous experts and scholars builds trust between those living in close contact with the subject matter and those who study it from a distance. Intentional dialogue helps build a relationship in which knowledge gained is shared with those most directly impacted and that the indigenous perspective remains at the forefront.

The guidelines for place-based instruction on the North Slope illustrate this approach insofar as they ensure the significance of place-based experiences in developing scientific knowledge. Placed-based research transforms abstractions about the arctic, climate change, environmental sustainability into particular questions of direct interest to students in local communities. Indigenous peoples should have an equal role in the research process. While local community members are interested in the scientific results, it is imperative that knowledge shared includes steps for remediation, when necessary. Taken together, these recommendations establish the context necessary for developing knowledge of interest to indigenous communities.

Educators and researchers use place and culture to improve science, technology, engineering, and mathematics (STEM) engagement on Alaska's North Slope and elsewhere. Integrating 
students' personal knowledge, Elder knowledge and scientific field research is a proven means of engaging students in STEM curricula. Alaska's North Slope provides the ideal place-based laboratory to develop innovative curricula and solutions to pressing problems. Connecting oral traditions with relevant scientific knowledge would provide ample material for future studies. For example, the study of traditional indigenous plant use could be combined with laboratory research to determine the medical properties of local plants. A current project examines antibacterial properties in North Slope plants and includes Elder interviews on the traditional use of the plants.

The combination of direct observation by indigenous experts and laboratory analysis strengthens student understanding and helps overcome the barriers associated with both Traditional and Western knowledge systems to produce a single field of study utilizing the methodological strengths of both systems. The ability to synthesize knowledge from both systems leads to informed learners and citizens.

\section{Acknowledgement}

We would like to acknowledge Ilisagivik Tribal College for their continued support, the American Indian Higher Education Consortium, University of Illinois Urbana Champaign, Smithsonian Institution National Museum of the American Indian, the Arctic Division of the American Society for the Advancement of Science, and the Arctic Slope Community Foundation; grants ASCF005 and ASC026.

In addition, we acknowledge the Biomedical Learning and Student Training (BLaST) program (University of Alaska Fairbanks), which is supported by the National Institute of General Medical Sciences of the National Institutes of Health under Award Numbers UL1GM118991, TL4GM118992, or RL5GM18990. The content is solely the responsibility of the authors and does not necessarily represent the official views of the National Institutes of Health.

Cathy Middlecamp (University of Wisconsin-Madison), Kriya Dunlap (University of Alaska Fairbanks) and Ray Barnhardt (University of Alaska Fairbanks) provided helpful discussions.

\section{References}

Anderson, M. (1996). Tending the Wilderness. Restoration and Management Notes. Ecological Restoration, 14(2), 154-166. https://doi.org/10.3368/er.14.2.154

Barnhardt, R. (1981). Culture, Community and the Curriculum. Retrieved from http://www.ankn.uaf.edu/curriculum/Articles/RayBarnhardt/CCC.html

Bartlett, C. (2006). Knowledge Inclusivity: "Two-Eyed Seeing” for Science for the 21st Century. In Wiber, M. \& Kearney, J. (Eds.). (4-5 November, 2005). Proceedings from the Workshop: Learning Communities as a Tool for Resource Management. (pp. 70-76). Halifax, Nova Scotia. 
Bartlett, C. (2011). Integrative Science / Toqwa'tu'kl Kjijitaqnn: The Story of our Journey in Bringing Together Indigenous and Western Scientific Knowledges. In Bernard, T. Rosenmeier, L. \& Farrell, S. (Eds.), Proceedings of the 2005 Debert Research Workshop. Ta'n Wetapeksi'k: Understanding From Where We Come (pp. 179-186). Debert, Nova Scotia, Canada: Eastern Woodland Print Communications, Truro.

Bartlett, C. (2012). The Gift of Multiple Perspectives in Scholarship/Integrative Science. In My Opinion" in University Affairs, 53(3), 41.

Bartlett, C., Marshall, M., Marshall, A., \& Iwama, M. (2012). Integrative Science and Two-Eyed Seeing: Enriching the Discussion Framework for Healthy Communities. In Hallstrom, L. Guehlstorf, \& N. Parkes, M. (Eds.), Beyond Intractability: Convergence and Opportunity at the Interface of Environmental, Health and Social Issues. UBC Press, Vancouver.

Battiste, M. (1998). Enabling the Autumn Seed: Toward a Decolonized Approach to Aboriginal Knowledge, Language, and Education. Canadian Journal of Native Education, 22, 16-27.

Battiste, M. (2002). Indigenous Knowledge and Pedagogy in First Nations Education: A Literature Review with Recommendations. Prepared for the National Working Group on Education and the Minister of Indian Affairs. Ottawa: Indian and Northern Affairs Canada.

Berkes, F. (1977). Fishery Resource use in a Subarctic Indian Community. Human Ecology, 5, 289-307. http://dx.doi.org/10.1080/08941920.2017.1315654

Bradley, J., Kutz, S., Jenkins., E., \& O’Hara, T. (2005). The Potential Impact of Climate Change on Infectious Diseases of Arctic Fauna. International Journal of Circumpolar Health, 64(5). http://dx.doi.org/10.3402/ijch.v64i5.18028

Burgess, P. (1999). Traditional Knowledge: A Report Prepared for the Arctic Council Indigenous Peoples' Secretariat. Copenhagen: Indigenous Peoples' Secretariat Arctic Council.

Cajete, G. (2000). Native Science: Natural Laws of Interdependence. (pp. 315) Santa Fé, NM: Clear Light Publishers. pp. 315.

Cajete, G., \& Pueblo, S. (2010). Contemporary Indigenous Education: A Nature-Centered American Indian Philosophy for the $21^{\text {st }}$ Century World. Futures, 42(10), 1126-32. https://doi.org/10.1016/j.futures.2010.08.013

Carmack, E., \& Macdonald, R. (2008). Water and Ice-Related Phenomena in the Coastal Region of the Beaufort Sea: Some Parallels between Native Experience and Western Science. Arctic, 61, 265-280. https://dx.doi.org/10.14430/arctic24

Castellano, M. (2000). Updating Aboriginal Traditions of Knowledge. In Dei, G. Hall, B. \& Rosenberg, D. (Eds), Indigenous Knowledges in Global Contexts: Multiple Readings of our World (pp. 21-36). Toronto. University of Toronto Press. 
Chapin, F. III., Robards, M., Huntington, H., Johnstone, J., Trainor, S., Kofinas, . . Naylor, R. (2006). Directional Changes in Ecological Communities and Social-ecological Systems: a Framework for Prediction Based on Alaskan Examples. American Naturalist, 168(S6), S36-S49. https://doi.org/10.1086/509047

Cochran, P. (2013). Wisdom of the Elders Radio Program S4E1. Wisdom of the Elders, Inc. http://www.wisdomoftheelders.org/wisdomradio/

Cruikshank, J. (2001). Glaciers and Climate Change: Perspectives from Oral Tradition. Arctic 54, 377-393. Retrieved from http://www.jstor.org/stable/40512394

Druckenmiller, M., Eicken, H., George, J., \& Brower, L. (2013). Trails to the Whale: Reflections of Change and Choice on an Inupiat Icescape at Barrow, Alaska. Polar Geography, 36(1-2), 5-29. http://dx.doi.org/10.1080/1088937X.2012.724459

Dubiel, R. F., Hasiotis, S. T., \& Semken, S. C. (1997). Hands-on Geology for Navajo Nation Teachers. Journal of Geoscience Education. 45(2), 113-116. https://doi.org/10.5408/1089-9995-45.2.113

Eicken, H., Kaufman, M., Krupnik, I., Pulsifer, P., Apangalook, L., Apangalook, P., Weyapuk, W. Jr., \& Leavitt, J. (2014). A Framework and Database for Community Sea Ice Observations in a Changing Arctic: An Alaskan Prototype for Multiple Users. Polar Geography, 37(1), 5-27. http://dx.doi.org/10.1080/1088937X.2013.873090

EPA. (2015). Environmental Protection Agency: Climate Impacts in Alaska. Retrieved From: http://www3.epa.gov/climatechange.html

Feinup-Riordan, A. (1990). Eskimo Essays: Yup'ik Lives and How We See Them. Rutgers University Press, New Brunswick, NJ.

Freeman, M., Milton, M., \& Carbyn, L. (1988). Traditional Knowledge and Renewable Resource Management in Northern Regions. Edmonton: IUCN Commission on Ecology and the Boreal Institute for Northern Studies.

Gruenewald, D. (2003). Foundations of Place: A Multidisciplinary Framework for PlaceConscious Education. American Educational Research Journal, 40, 619-654. https://doi.org/10.3102/00028312040003619

Hatcher, A., \& Bartlett, C. (2010). Two-Eyed Seeing; Building Cultural Bridges for Aboriginal Students. Canadian Teacher Magazine, May, 14-17.

Hatcher, A., Bartlett, C., Marshall, A., \& Marshall, M. (2009). Two-Eyed Seeing in the Classroom Environment: Concepts, Approach and Challenges. Canadian Journal of Science Math Technology Education. 9(3), 141-153. http://dx.doi.org/10.1080/14926150903118342

Huntington, H. (2000). Using Traditional Ecological Knowledge in Science: Method and Applications. Ecological Applications. 10, 1270-1274. https://doi.org/10.1890/1051-0761(2000)010[1270:UTEKIS]2.0.CO;2 
Huntington, H. and the Communities of Buckland, Elim, Koyuk, Point Lay and Shatoolik. (1999). Traditional Knowledge of the Ecology of Beluga Whales (Delphinapterus leucas) in the Eastern Chukchi and Northern Bering Seas, Alaska. Arctic, 52, 49-61. http://www.jstor.org/stable/40512180

Huntington, H., Gearheard, S., Mahoney, A., \& Salomon, A. (2011). Integrating Traditional and Scientific Knowledge through Collaborative Natural Science Field Research: Identifying Elements for Success. Arctic, 64, 437-445. http://www.jstor.org/stable/41319238

IISH website, http://www.integrativescience.ca

Iwama, M., Marshall, M., Marshall, A., \& Bartlett, C. (2009). Two-Eyed Seeing and the Language of Healing in Community-based Research. Canadian Journal Native Education, 32, 3-23. https://dx.doi.org/10.1186\%2Fs13011-015-0021-6

Jones, C., Kielland, K., Hinzman, L., \& Schneider, W. (2015). Integrating Local Knowledge and Science: Economic Consequences of Driftwood Harvest in a Changing Climate. Ecology and Society, 20(1), 25 http://dx.doi.org/10.5751/ES-07235-200125

Jones-Sparck, L. (2011). Effects of Modernization on the Cup'ik of Alaska. In Ray Barnhardt \& Angayuqaq Oscar Kawagley (Eds.), Alaska Native Education. Chicago, IL, University of Chicago Press.

Kawagley, A. O. (2006). A Yupiaq Worldview: A Pathway to Ecology and Spirit. (pp. 8-18) Waveland Press: Long Grove, IL.

Kawagley, A.O., \& Barnhardt, R. (1998). Education Indigenous to Place: Western Science Meets Native Reality. Alaska Native Knowledge Network. Retrieved from http://ankn.uaf.edu/curriculum/Articles/BarnhardtKawagley/EIP.html

Kawagley, A.O., \& Barnhardt, R. (1999). Education Indigenous to Place: Western Science Meets Native Reality, In Smith, G. \& Williams, D. (Eds.), Ecological Education in Action: on Weaving Education, Culture, and the Environment (pp. 117-140), State University of New York Press: Albany, NY

Kimmerer, R. (2002). Weaving Traditional Ecological Knowledge into Biological Education: A Call to Action. BioScience. 52(5), 432-438. https://doi.org/10.1641/0006-3568(2002)052[0432:WTEKIB]2.0.CO;2

Kirby, K. (2014). Place in the City: Place-Based Learning in a Large Urban Undergraduate Geoscience Program. Journal of Geoscience Education, 62, 177-186. https://doi.org/10.5408/12-396.1

Knudson, S. (2015). Integrating the Self and the Spirit: Strategies for Aligning Qualitative Research Teaching with Indigenous Methods, Methodologies, and Epistemology. Forum: Qualitative Social Research. 16(3), Article 4. http://nbn-resolving.de/urn:nbn:de:0114-fqs150347 
Krupnik, I., \& Jolly, D. (Eds.). (2002). The Earth is Faster Now: Indigenous Observations of Arctic Environmental Change. Arctic Research Consortium of the United States, Fairbanks, Alaska, USA.

Lieberman, G., \& Hoody, L. (1998). Closing the Achievement Gap: Using the Environment as an Integrating Context for Learning. (pp. 106) State Education and Environment Roundtable. San Diego, CA.

Locust, C. (1988). Wounding the Spirit: Discrimination and Traditional American Indian Belief Systems. Harvard Educational Review, 58, 315-331. https://doi.org/10.17763/haer.58.3.e0r224774008738p

Loring, P., \& Duffy, L. (2011). Managing Environmental Risks: The Benefits of a Place-based Approach. Rural Remote Health, 11(3), 1800.

Lowan-Trudeau, G. (2015). Contemporary Studies in Environmental and Indigenous Pedagogies: A Curricula of Stories and Place. Environmental Education Research, 21(4), 652-653. http://dx.doi.org/10.1080/13504622.2014.943561

Machtmes, K., Johnson, E., Fox, J., Burke, M., Harper, J., Arcemont, L., . . . Aguirre, R. (2009). Teaching Qualitative Research Methods through Service-Learning. The Qualitative Report, 14, 155-164. http://nsuworks.nova.edu/tqr/vol14/iss1/9/

MacIvor, M. (1995). Redefining Science Education for Aboriginal Students. In: Battiste, M.A. \& Barman, J. (Eds.), First Nations Education in Canada: The Circle Unfolds (pp. 73-98), University of British Columbia Press: Vancouver, CN

Mander, J. (1991). In the Absence of the Sacred: The Failure of Technology and the Survival of the Indian Nations. (pp. 258). Sierra Club Books: San Francisco, CA

Marshall, A., Marshall, M., \& Iwama, M. (2010). Approaching Mi'kmaq Teachings on the Connectiveness of Humans and Nature. In: Bondrup- Nielsen, S., Beazley, K., Bissix, G., Colville, D., Flemming, S., Herman, T., . . . O’Grady, S. (Eds.). Ecosystem Based Management: Beyond Boundaries. Proceedings of the Sixth International Conference of Science and the Management of Protected Areas, 21-26 May 2007. Acadia University, Wolfville, Science and Management of Protected Areas Association, Wolfville, NS.

McCarty, T. (2002). A Place to Be Navajo-Rough Rock and the Struggle for Self-Determination in Indigenous Schooling. Journal of Anthropological Research, 59(3). Retrieved from http://www.jstor.org/stable/3631522

McGloin, C., Marshall, A., \& Adams, M. (2009). Leading the Way: Indigenous Knowledge and Collaboration at the Woolyungah Indigenous Centre. Journal of University Teaching \& Learning Practice, 6(2), Article 4.

Medin, D., \& Bang, M. (2014). Who's Asking? Native Science, Western Science and Science Education. MIT Press, Cambridge, MA.

Nadasdy, P. (1999). The Politics of TEK: Power and the Integration of Knowledge. Arctic 
Anthropology, 36, 1-18.

Nakashima, D. (1988). Eider Ecology from Inuit Hunters. In Nakashima, D. \& Murray, D. (Eds.), The Common Eider of Eastern Hudson Bay: A Survey of Nest Colonies and Inuit Ecological Knowledge. Environmental Studies Revolving Fund Report No. 102. Ottawa, Canada.

Nakashima, D. (1993). Astute Observers on the Sea Ice Edge: Inuit Knowledge as a Basis for Arctic Comanagement. In: Inglis JT. (Ed.), Traditional Ecological Knowledge: Concepts and Cases. (pp. 99-110). Museum of Nature and International Development Research Centre. Ottawa. Canada.

Napoleon, H. (1991). Yuuyaraq: The Way of the Human Being. In Eric Madsen-Fairbanks (Ed.), Center for Cross-cultural Studies, University of Alaska Fairbanks. Retrieved from http://ankn.uaf.edu/Publications/Books/Yuuyaraq.pdf

Nelson, R. (1983). Make Prayers to the Raven. University of Chicago Press. Chicago, IL.

Nicholas-Figueroa, L. (2017). Traditional Ecological Knowledge of STEM Concepts in Informal and Place-Based Western Educational Systems: Lessons from the North Slope, Alaska (Unpublished doctoral dissertation). University of Alaska Fairbanks. Fairbanks, AK.

Nicholas-Figueroa, L., Barnhardt, R., Duffy, L., Dunlap, K., van Muelken, M., \& Middlecamp, C. (2015). Delivering Post-Secondary STEM Education on the North Slope, Alaska: Resilience and Adaption. International Research in Education, 3(2), 80-92. https://doi.org/10.5296/ire.v3i2.7555

Nicholas-Figueroa, L., Hare, R., van Muelken, M., Duffy, L., \& Middlecamp, C. (2016). Ilisagivik Tribal College Summer Climate Program: Teaching STEM Concepts to North Slope Alaska High-school and Middle-school Students. Journal of Environmental Studies and Science. p. 1-10. Retrieved from http://link.springer.com/article/10.1007/s13412-016-0413-6

Palmer, H., Douglas, E., Watson, M., Kloesel, K., \& Palmer, K. (2009). Xoa:dau to Maunkaui: Integrating Indigenous Knowledge into an Undergraduate Earth Systems Science Course. Journal of Geoscience Education, 57(2), 137-144 https://doi.org/10.5408/1.3544247

Pearce, T., Ford, J., Laidler, G., Smit, B., Duerden, F., Allarut, M., . . . Wandel, J. (2009). Community Collaboration and Climate Change Research in the Canadian Arctic. Polar Research, 28, 10-27. https://doi.org/10.1111/j.1751-8369.2008.00094.x

Potter, S., Caffrey, E., \& Plante, E. (2003). Integrating Service Learning into the Research Methods Course. Teaching Sociology, 31, 38-48.

Reano, D., \& Ridgway, K. (2015). Connecting Geology and Native American Culture on the Reservation of Acoma Pueblo. New Mexico, USA. Geological Society of America Today, 25(8). https://doi.org/10.1130/GSAT-G235GW.1 
Richards, R. (1997). What the Natives Know: Wild Mushrooms and Forest Health. Journal of Forestry (September). 5-10. In Turner, N. (2014). Ancient Pathways, Ancestral Knowledge Ethnobotany and Ecological Wisdom of Indigenous Peoples of Northwestern North America Montreal, (pp 554) McGill-Queen's Press: Montreal, Canada.

Riggs, E. (2004). "Fostering Indigenous Earth Science: Increasing Native American Participation in the Earth Science Enterprise" invited abstract for the 2004 Fall meeting of the American Geophysical Union, special session on "Diversity and Equity in the Earth and Space Sciences: 1. Global Perspectives on the Issues and Obstacles"

Rothschild, R., \& Duffy, L. (2002). Methylmercury in the Hair of Subsistence Food Users in a Rural Alaskan Village. Alaska Medicine, 44, 2-8.

Semken, S. (2005). Sense of Place and Place-Based Introductory Geoscience Teaching for American Indian and Alaska Native Undergraduates. Journal of Geoscience Education. 53(2), 149-157. https://doi.org/10.5408/1089-9995-53.2.149

Semken, S., \& Morgan, F. (1997). Navajo Pedagogy and Earth systems. Journal of Geoscience Education, 45(1), 109-112. https://doi.org/10.5408/1089-9995-45.2.109

Stephenson, R. (1982). Nunamiut Eskimos, Wildlife Biologists, and Wolves. In Harrington, F.H., \& Pacquet, P.C. (Eds.), Wolves of the World. (pp. 434-439). Noyes: Park Ridge, NJ.

Streever, B., Suydam, R., Payne, J., Shuchman, R., Angliss, R., Balogh, J., . . . Yokel, D. (2011). Environmental Change and Potential Impacts: Applied Research Priorities for Alaska's North Slope. Arctic, 63(3), 390-397.

Turner, N., Ignace, M., \& Ignace, R. (2000). Traditional Ecological Knowledge and Wisdom of Aboriginal Peoples in British Sense of Place and Place-based Introductory Geoscience Teaching for American Indian and Alaska Native Undergraduates. Ecological Applications. 10(5), 1275-1287. https://doi.org/10.1890/1051-0761(2000)010[1275:TEKAWO]2.0.CO;2

Van Doren, G., \& Duffy, L. (2016). Teaching Chemistry in Rural America: A Comparative Study Examining Innovative Informal Education and Applied Science Approaches to Improving Engagement. International Research in Education, 4(2). https://doi.org/10.5296/ire.v4i2.9537

Weatherhead, E., Gearheard, S., \& Barry, R. (2010). Changes in Weather Persistence: Insight from Inuit Knowledge. Global Environmental Change, 20, 523-528. https://doi.org/10.1016/j.gloenvcha.2010.02.002

Webster, D., \& Zibell. W. (1970). Inupiat Eskimo Dictionary. 1970 Summer Institute of Linguistics, Inc. Box 1028. Fairbanks, AK 99701. Library of Congress Catalog Card No. 76-632478. p. 108-109. Retrieved from: http://library.alaska.gov/hist/hist_docs/docs/anlm/200078.pdf

Woodhouse, J., \& Knapp, C. (2000). Place-Based Curriculum and Instruction: Outdoor and Environment Education Approaches. ERIC Digest. Retrieved from https://eric.ed.gov 


\section{Copyright Disclaimer}

Copyright for this article is retained by the author(s), with first publication rights granted to the journal.

This is an open-access article distributed under the terms and conditions of the Creative Commons Attribution license (http://creativecommons.org/licenses/by/3.0/). 